\title{
Analysis of Historical Material of Islamic Civilization in Historical Textbooks at High School
}

\author{
Tio Anggara \\ Graduate School \\ Universitas Negeri Yogyakarta \\ Yogyakarta Indonesia \\ tio.anggara2016@student.uny.ac.id
}

\author{
Dyah Kumalasari \\ Graduate School \\ Universitas Negeri Yogyakarta \\ Yogyakarta, Indonesia \\ dyah_kumalasari@uny.ac.id
}

\begin{abstract}
This study aims to analyze the breadth of the material history of Islamic civilization contained in Indonesian history textbooks for compulsory 10th grade in high school published by Erlangga. The results of the study show that: (1) the breadth of the material of the theory of entry and the development of religion and Islamic culture into Indonesia is quite good, this can be seen with the material presented about several theories of entry, and the influences of Islam in various fields of community life are good but the example presented cannot describe the full material content. (2) the breadth of material Development of people 's lives, government, and culture during the Islamic kingdoms in Indonesia has been extensive, this can be seen from the material presented regarding the kingdoms that cover most of the territory in Indonesia. However, the focus of the discussion was mostly still centered on palace life (royal environment) which resulted in studies of the conditions of social life of the people still not deeply touched.
\end{abstract}

Keywords - textbook analysis, Islamic civilization, high school

\section{INTRODUCTION}

Education is one of the important things for humans to improve their quality of life. The education process can be carried out by humans both through formal and non-formal institutions, because basically the meaning of education is a collection of new experiences that can improve the quality of human life. So far education in Indonesia has always been associated with education carried out by formal institutions such as schools. Education carried out aims to prepare humans to be able to compete with the international world, this is due to the existence of globalism that allows goods and services to enter other countries without obstacles. With this reality, the quality of education in Indonesia must be an important concern of all elements, both the government and the general public. However, there are many inequalities in various aspects of education in Indonesia, including many schools and colleges whose buildings are damaged, ownership and use of learning media is low, library books are incomplete [12]

The problem of education is a problem that must be immediately sought for a solution, because basically the high quality of education will affect the results of the education, namely students. One step taken by the government to improve the quality of education in Indonesia is by updating the curriculum. The latest curriculum applied in Indonesia is Curriculum 2013.
The implementation of the new curriculum is expected to improve the quality of education significantly, this starts from the fact that the implementation of the new curriculum is the answer and innovation for the demands of changing times. However, in practice the implementation of Curriculum 2013 received several criticisms because it was considered a lack of preparation both from the Ministry of Education, educational institutions, and even to the readiness of teaching materials that experienced delays in the distribution process [13].

Improving the quality of education can be done in various ways, one of which can be done is by providing teaching materials or textbooks with quality lessons. Preparation of quality textbooks requires not a little time due to the need for careful preparation, and the selection of material that fits your needs. However, with the implementation of a rushed curriculum that is very influential on the procurement of textbooks, the quality of textbooks will be less optimal because the time of compiling is relatively short. As Totok Amin Soefijanto explained, the content in the textbooks in Curriculum 2013 is still not ideal because it still contains information so that it is less detailed, and Curriculum 2013 textbook should prioritize content so that students understand more about the field of study being taught [14]. The statement indicates that the current circulating textbook cannot fully help students improve their learning achievement.

Analysis of textbooks important to do to improve the quality of textbooks used as one of the main learning resources at school. In this case, a study of the contents of a textbook on historical subjects is conducted to determine the quality of textbooks, especially those related to the material history of Islamic civilization in Indonesia. Generally, the study of the content of textbooks will provide benefits to the government as one of the foundations in making policies related to the provision of textbooks, while for teachers this study can be used as one of the considerations in choosing the textbooks to be used. The quality of the content of the textbooks used in learning carried out by students will greatly affect the quality of education, so studies need to be carried out in depth to find out the weaknesses that are still contained in the textbook. 
Another weakness in the preparation of textbooks in Indonesia is that there is a hand in the government, where textbooks are used as a tool to legitimize their power [1] especially textbooks on historical subjects. So far, the government is considered too much to interfere in the preparation of historical textbooks, historical events should be told to students as they are without loading other interests that could lead to bias in the material presented.

One of the important things that can be used to improve the quality of education and student achievement is to read. This fact requires the availability of quality reading material, especially in the content section, with the contents of quality reading books, the insights of students will increase. However, the limited knowledge of the quality standards of a textbook is a problem in choosing the textbook to be used. Therefore, it is necessary to conduct studies that can explore the quality of a textbook as one of the supporting materials or even the main source for students.

Analysis of textbooks basically covers many things, as contained in the textbook assessment instruments issued by the Ministry of Education and Culture that the assessment of textbooks at least includes three main aspects, including: content eligibility, presentation feasibility, and language feasibility. The study conducted by researchers focused on the issue of the feasibility of the contents of a textbook, an analysis of the feasibility of this content will be focused on the breadth of material history of Islamic civilization in Indonesia contained in Indonesian history textbooks. This is due to limited time and funds so that the research carried out only focuses on the issue of the vast material history of Islamic civilization in Indonesian history textbooks for compulsory class $\mathrm{X}$ in high school published by Erlangga.

\section{ISLAMIC CIVILIZATION IN INDONESIA AND TEXTBOOK ANALYSIS}

\section{A. History of Islamic Civilization in Indonesia}

Talking about the history of civilization always refers to the cultural heritage of humans living in a region. The results of the heritage are then identified characteristics that distinguish it from other regions. Islam is one of the divine/samawi religions, which means a religion revealed by God to humans. However, in the process of spreading Islam requires the role of humans, this can be seen from the spread of influence to various regions. As an example of how the influence of religion and culture enters and develops in Indonesia from its native region in Arabia. The role of traders who make voyages to Indonesian territory has a very important role in the spread.

The concept of Islamic civilization is understood as part of Islamic culture which includes aspects of morality, art, and science, and includes culture, building art, the state system, and other sciences. While the history of Islamic civilization contained in journals and textbooks used by researchers as reference material outlines some basic material, these materials will then serve as guidelines for researchers to see the quality of content contained in Indonesian history textbooks published by Erlangga. The following are some of the sources referred to by the researcher.

Hadi W.M, A., Sayhid, A., Yatim, B., Pranowo, B, Ambary, H. M,. Abdullah, I. T,. Madjid, D,. Damami, M,. Fathurahman, O,. Putuhena, S,. \& Tjandrasasmita, U. The material presented in this book includes materials about: 1). Arrival of Islam and Islamization, 2). Islamic kingdoms, 3). Keprajuritan Islamic period, 4). Thought and institution of Islamic thought, 5). Islamic social cultural tradition, 6). Islamic intellectual tradition and discourse, 7). Islam and the formation of Javanese culture, 8). Literary and linguistic traditions, 9). Malay language: lingua franca Islam, 10). Economy and trade, 11). Material culture, 12). Formation and development of institutions and institutions of Islamic law, 13). Development of Islamic education institutions, 14). Order and development, 15). Muslim response to colonialism, 16). Hajj trip from time to time. [5]

Meanwhile the book on the history of Islamic civilization in Indonesia was published by SKI Faculties Adab UIN Yogyakarta dividing the history of Islamic civilization in Indonesia into several basic material as follows: 1). Nusantara at religious turning points, 2). The entry of Islam into the Nusantara, 3). Islamic kingdoms in Sumatra, 4). Islamic kingdoms in Java, 5). Islamic kingdoms based in Maluku, 6). Islamic kingdoms based in Sulawesi, 7). History of Islamic education in Indonesia, 8). Islamic Economics in Indonesia, 9). The discourse of contemporary Islamic intellectuals on the map, the history of Islam in Indonesia, 10). National Awakening, 11). History of Islamic political parties in Indonesia from the Old Order to the New Order, 12). Contemporary Islamic social movement. [7]

The history book of Islamic civilization Dirasah Islamiyah II written by Badri Yatim contains material on the history of Islamic civilization in Indonesia which includes: 1). Arrival of Islam to Indonesia, 2). Islamic kingdoms before Dutch colonialism, 3). Islamic kingdoms after Dutch colonialism, 4). Indonesian Islam: Modern and contemporary times, 5). Islamic civilization in Indonesia. [9]

\section{B. Textbook Analysis}

According to Sitepu [4] seen from its use in the classroom, textbooks are divided into basic textbooks and supplementary textbooks. The main textbook is a book that is compiled by referring to the curriculum that is being applied and used by teachers and students as the main source of learning. While supplementary textbooks are books other than the main books that are considered still relevant to the material contained in the 
curriculum to support the process of learning. Looking at the above definition, the Indonesian history textbook published by Erlangga is one example of the main textbook. So far in Indonesia, textbooks are still used as a basic learning resource by teachers and students.

Textbooks or better known as textbooks / textbooks are one of the important elements in a learning, therefore the quality of a textbook becomes very important, so some standard criteria are needed as the basis. According to the BSNP as cited by Purwanta [3] the feasibility of a textbook must meet the following four criteria (a) Material; (b) presentation; (c) language and readability; (d) graphics. The four elements are all elements of the compilation of textbooks, where the fulfillment of the quality of all the elements determines the conveyance of information from the author to the reader.

Meanwhile according to Pingel as quoted [2] analyzing the contents of a textbook using a qualitative approach must include the following: 1) hermeneutic analysis, used to explore hidden meanings and messages in a text; 2) linguistic analysis, involves examining words and terminology with controversial meanings; 3) cross-cultural analysis, bilateral and multilateral analysts examine each textbook to examine bias; 4) discourse analysis, the researcher deconstructed the textbook content to identify what information, groups and events were written by the author; 5) contingency analysis, the new method combines quantitative and qualitative techniques for the analysis of text and image representations.

Analysis of the quality of the content of textbooks, especially in the knowledge dimension KI-3, was then re-developed into several sections, including material coverage, material accuracy, sophistication and contextual. In this study the researcher will conduct a study of one of the dimensions of knowledge contained in the textbook assessment instrument issued by the Ministry of Education and Culture, namely the breadth of material contained in the textbook.

\section{Materi, contoh, dan Evaluasi yang disajikan minimal mencerminkan jabaran substansi materi yang terkandung dalam kompetensi inti 3 (KI-3) dan kompetensi dasar (KD) sesuai dengan tingkat pendidikan peserta didik.}

The above statement implies that a textbook will be said to be broad if the material, examples, and evaluations presented in the textbook are compatible with the basic competencies. So, from that the study of the breadth of material in this study will see whether the textbook has fulfilled the bills of material contained in the Indonesian history textbook published by Erlangga.

\section{METHODOLOGY}

This research is a qualitative research design with a content analysis approach. This study aims to analyze the material content of the history of Islamic civilization contained in the mandatory Indonesian class $\mathrm{X}$ textbook in high school published by Erlangga. Content analysis research is usually carried out in journalistic research but can also be used for other social studies including historical research. Here are some definitions of content analysis according to several experts.

Content analysis is a systematic technique for analyzing message content and how to express messages. This definition shows that the main purpose of content analysis must be to make inference. Content analysis always involves connecting or comparing findings with several criteria or theories [10].

Content analysis is a research method that does not use humans as the object of research. Content analysis uses symbols or text that are in certain media, then the symbols or text are processed and analyzed [6].

Content analysis activities are intended to determine the meaning, position and relationship between several concepts, policies, programs, activities, events that occur or that occur to further find out the benefits, results or impacts of these thing [8].

This research was conducted to see the breadth of textbook material, while the sample used was material about the history of Islamic civilization contained in Chapter V of the textbook. This research is conducted through three stages, namely the preparation, implementation and completion stages. Content analysis research allows researchers to act as a single instrument, this is related to the analysis carried out by researchers that allows a researcher to carry out an interpretation of the document that is the subject of his study. As explained by Zhang and Wildemuth [11] below.

"... qualitative content analysis emphasizes integrated views of speech and texts specific contexts. Qualitative analysis goes beyond counting words or texts, meaning themes and patterns that may be manifest or latent in a particular text. It allows social reality researchers to understand in a subjective but scientific manner."

The subjective term put forward by Zhang \& Wildemuth refers to the authority of the researcher to analyze the source of data obtained, because basically in this study the researcher was placed as an instrument. Nevertheless, the use of subjective terms in this study is still based on scientific ways of making decisions.

The techniques used for this research include the modified steps from Zang \& Wildemuth [11] which includes several steps as follows.

\section{a. Prepare data}

The data to be examined in this study are Indonesian history textbooks for class $\mathrm{X}$ published by Erlangga. 


\section{b. Define analysis units}

The unit of analysis for textbooks includes every material contained in the discussion of the history of Islamic civilization in Indonesia.

c. Create categories

The category used in this study is the breadth of the material contained in the book according to the material content in basic competence.

\section{d. Coding}

Coding is done to answer research questions; coding is given to material points of the history of Islamic civilization contained in history textbooks. Coding is the result of analysis of the content of material contained in the textbook.

e. Presenting data and data analysis

Data obtained from the results of the coding are then presented which are then analyzed to get conclusions on the research questions.

\section{TABEL I. TEXTBOOK ASSESSMENT ISNTRUMENT}

\begin{tabular}{|l|l|l|l|l|}
\hline \multirow{2}{*}{$\begin{array}{c}\text { Analysis of } \\
\text { textbook aspects }\end{array}$} & \multicolumn{3}{|c|}{ Material breadth } & $\begin{array}{c}\text { Concl } \\
\text { usion }\end{array}$ \\
\hline & Material & Example & evaluation & \\
\hline $\begin{array}{l}\text { Theory of entering } \\
\text { Islam into }\end{array}$ & & & & \\
Indonesia & & & \\
\hline $\begin{array}{l}\text { Development of } \\
\text { Islam in Indonesia }\end{array}$ & & & & \\
\hline $\begin{array}{l}\text { The development } \\
\text { of society, } \\
\text { government and } \\
\text { culture of the } \\
\text { Islamic kingdoms }\end{array}$ & & & & \\
\hline $\begin{array}{l}\text { Examples of relics } \\
\text { that still exist in } \\
\text { the lives of today's }\end{array}$ & & & & \\
society & & & \\
\hline
\end{tabular}

Research instruments are used to see the breadth of material in each component that is adjusted to the bills contained in the textbook. The breadth of material in the textbook that is the focus of the analysis includes material, examples, and evaluations. The material contained in the textbook is said to be broad if the material presented has been able to answer the bills contained in the basic competencies: 1) The material on the theory of entering Islam into Indonesia is widely considered if the material, examples, and training have been able to describe some of the theories of the entry of Islam into Indonesia, which were put forward by several experts, especially based on the location of origin and time of arrival. 2) Material about the development of Islamic religion and culture in Indonesia is widely considered if the material, examples and evaluations presented have been able to describe the influence of Islamic religion and culture in Indonesia in various fields of community life. 3) Material development of people's lives, government, and culture is widely considered if the material, examples and training have been able to describe the development of people's lives, government, and culture during the period of Islamic kingdoms as a whole. 4) Material about examples of relics that still exist in people's lives today is widely considered if the material, examples, and training have been able to show the forms of relics of Islamic civilization of the past that still exist and affect the lives of today's Indonesian society.

\section{IV.RESULT AND DISCUSSION}

\section{A. Theory of the entry of religion and Islamic culture into Indonesia}

In accordance with the instruments that have been made material about the theory of the entry and development of religion and culture of Islam in Indonesia, at least found in the three elements of the textbook, namely in the translation of material, examples, and training.

\section{Material}

The material presented includes material on the theory of the entry of Islam into Indonesia based on the origin and time of arrival which includes Gujarat Theory supported by Snouck Hurgronje, WF Suttherheim, and BHM Velekke according to this theory that Islam was brought by traders from Gujarat, India around the 13th century. The theory of Mecca is supported by Buya Hamka and JC van Leur who claim that religion and Islamic culture in Indonesia were brought by Arab traders in the 7th century. The Persian theory was supported by Hosein Djajaningrat who claimed that religion and Islamic culture in Indonesia were brought by the Persians in the 13th century.

The material about the theory of the entry of Islam into Indonesia can be found in the textbook on page 221. The material presented on the theory of the entry of Islam into Indonesia has been included in the broad category because it is in accordance with basic competencies, namely minimally presenting material on Indonesian Islamic theory of entry based on location and time.

\section{Example}

\section{Not found in the textbook}

\section{Evaluation}

Evaluation is a form of evaluation of the success of a learning, so its existence is very important to see the improvement of students' abilities. The training on the theory of the entry of Islam into Indonesia can be seen in the findings in the textbook as follows.

Evaluation, Multiple choice, page 254, number 1 The existence of the Ark (Tabuik) ceremony in West Sumatra supports the theory that Islam in Indonesia is brought in by people.
a. Gujarat
d. Persia
b. Arabic
e. Malaysia
c. Africa

Evaluation, Essay, page 260, number 1.

Explain theories about the importance of Islamic religion and culture to Indonesia. 
The method for exploring the breadth of material demanded by the Ministry of Education and Culture, is a presenting evaluation which can explore materials regarding the theory of entry into Islam into Indonesia.

\section{B. Development of religion and Islamic culture in Indonesia}

An assessment of the breadth of material regarding the development of religion and Islamic culture in Indonesia will be carried out by looking at the availability of material, examples, and evaluations that can describe the development of the lives of Indonesian people affected by religion and Islamic culture.

\section{Material}

Islam as a religion and culture has a significant influence on the development of people's lives in Indonesia in various fields. In the Indonesian history textbook published by Erlangga the developments involved include developments in politics (pages 217218), socio-cultural fields (page 218), the field of language (page 218), the field of education (page 218), how to dress (page 218) page 218), the field of building art (219), the field of literary art (page 218), the field of art (page 219), the field of calligraphy (page 220), the field of dance and music (pages 220-221).

The material presented on the development of religion and Islamic culture in various fields of life in Indonesian society is very broad and can provide knowledge to students.

\section{Example}

An example is an illustration given to give an illustration to students about the material presented to students in order to facilitate students in understanding the material presented. So, in this study the examples given must be able to provide an overview of the development of religion and Islamic culture in Indonesia. The findings in the textbook about the examples in question include; the language field (page 218) discusses the use of the name of the day in Indonesia which comes from Arabic. Literary art (page 219) about examples of the names Hikayat, Babad, and Suluk that are well known in Indonesia. Fine art (page 219) concerning puppets and (page 220) concerning statues and sculptures in the mosque building. The art of calligraphy (page 220) concerning the form of calligraphy originating from Persia. Dance and music (p. 220-221) concerning the art of Debus, Seudati, and Zapin.

Examples given about the development of religion and Islamic culture in Indonesia have been included in a broad category. This can be seen from some examples given to describe the material previously delivered.

\section{Evaluation}

The training given must be able to see the students' ability to understand the material about religious development and Islamic culture in Indonesia. The findings in the textbook can be seen in the form of group assignments (pages 221-222) students are asked to do drama about the process of entering and developing religion and Islamic culture in Indonesia.

\section{The development of the life of the community, government, and culture of the Islamic kingdom in Indonesia}

This material is presented in the text in the form of material translation concerning Islamic kingdoms in Indonesia which has a major influence on the development of Indonesian history but does not specifically describe developments (society, government, culture) so that analysis is needed to find out the material content in it. Analysis is carried out on material, examples and evaluations that can describe the development of community life, government, and culture in each kingdom.

\section{Material}

Material about the development of people's lives, government, and culture will be carried out on each kingdom presented in the textbook.

a. Samudra Pasai, the first kingdom presented is Samudra Pasai, while the material on the development of people's lives is on page 225 regarding the way of life of the Pasai community based on Islamic Shari'a. While material on the development of the government (page 223) the establishment of Samudra Passai, (pages 224-225) the heyday, and (page 225) concerning the final period of the Ocean Pasai. While material about cultural development is not found in the textbook.

b. The Malacca Sultanate, material about the development of community life was not conveyed in the textbooks, material on government development presented included the location of the Malacca sultanate (page 227), the heyday is on page (227-228), and the final period on page 228. Material concerning development culture is not included in the textbook.

c. The Sultanate of Aceh Darussalam, the material presented on community life development is on page 230 regarding the economic activities of the Acehnese. Material information on government development is on page 229 regarding the beginning of the establishment of the Aceh Sultanate, page 230 concerning Aceh's heyday, and the decline of the Aceh sultanate on page 230 Material on cultural development is on page 230 regarding the formation of governance laws, and the development of literature and its authors.

d. Demak Sultanate, the material presented included material on the development of people's lives on page 232. Government development page 231 concerning the establishment of the Demak Sultanate, page 232 concerning the heyday of the Demak Sultanate. Material about cultural development is not delivered in the textbook. 
e. Mataram Sultanate, page 236 discusses material about the development of the life of the Mataram community. Pages 234-235 concerning the establishment of the Mataram Sultanate as part of the material development of government, the heyday of the Mataram period is discussed on page 235. The material on cultural development is discussed on page 236 regarding the development of Kejawen culture.l

f. Banten Sultanate, material about the development of people's lives is not discussed in the textbook. The development of government discusses the establishment of the Banten Sultanate on page 240. Material about cultural development is not discussed in the textbook.

g. Gowa-Tallo Sultanate, material on the development of community life is discussed on page 244 regarding the economic activities of the people of Makassar. Material on government development discusses the alliance of Gowa-Tallo (page 245) and the heyday of Makassar (page 245) and the significance of the Makassar sultanate. While the material on cultural development is on page 247 regarding the adoption of customary law to regulate the norms of life called Pangadakkan.

h. Ternate Sultanate, the material presented regarding the development of people's lives was not conveyed. The material on the development of government is on page 247 regarding the establishment of the Sultanate of Ternate, its glory. Material about cultural development is not delivered.

i. Tidore Sultanate, material regarding the development of people's lives is not presented. While material on the development of government is presented on page 248 regarding the location and area of power, the heyday is presented on page 251 . Material about cultural development is not conveyed in the textbook.

j. The material presented on the development of people's lives, government, and culture in the textbook is still focused on discussing the development of the government and still not discussing the development of people's lives, and culture. So that the breadth of material falls into the sufficient category.

\section{Example}

In order to facilitate the learning done by students, it is necessary to present an example that can provide an overview of the material regarding the development of the life of society, government, and the culture of the Islamic kingdom. The example findings in the textbook regarding the development of government are illustrations of the location and territory of his authority. While examples of cultural developments presented include illustrations of mosque and palace buildings. As a discussion of the material above the example presented is also still centered on the example of government development.

\section{Evaluation}

The evaluations presented on the historical material of the development of the life of the community, government, and culture in the textbook can be seen in the daily task section page 243,252 , and evaluation pages254-260.

\section{CONCLUSION}

Based on the results of the research carried out it can be concluded that: 1 . The material regarding the theory of the entry of Islam into Indonesia is quite extensive, this is evidenced by the material presented about the theory of the entry of Islam into Indonesia based on their time and place of origin. Examples still not presented; 2. Material about the development of Islamic religion and culture in Indonesia has been very extensive with the presentation of material, examples, and evaluations that can describe the development of Islamic religion and culture in various elements of Indonesian people's lives; 3. Material about the development of people's lives, government, and culture can be explained in two aspects, the first is the presentation of Islamic kingdoms which is enough to present Islamic kingdoms which have a major influence on the development of Indonesian history, but still need to present several kingdoms Another Islam that develops in Indonesia. Furthermore, the material content in each kingdom concerning the development of people's lives, government, and culture is also sufficient, the material presented is too focused on the discussion of development of government and still not discussing the condition of society during the Islamic kingdoms. in just a few kingdoms; 4. Material about examples of legacies that still apply to the lives of Indonesians today have not yet gotten a place separately, the material presented is still based on the discussion of other material

\section{REFERENCE}

[1] Mulyana, A. Nasionalisme dan Militerisme: Ideologisas Historiografi Buku Teks Pelajaran Sejarah di SMA. Paramita, Vol. 23, No. 1, 2013. Retrieved from https://journal.unnes.ac.id/nju/index.php/paramita/article/ view/2498

[2] Nicholls, J. Methods in School Textbook Research. International Journal of Historical Learning, Teaching and Research, 3(2), 2016, pp. 11-26. Retrieved from http://centres.exeter.ac.uk/historyresource/journal6/wholej ournal.pdf\#page $=11$

[3] Purwanta, H. Kriteria Penyusunan Buku Teks Mata Pelajaran Sejarah. Widya Dharma: Jurnal Pendidikan. Vol. 20, No 2.,2010 Retrieved from https://repository.usd.ac.id/5906/1/Full\%20text\%20Kriteri a\%20Widya.pdf

[4] Sitepu, B. P. Memilih Buku Pelajaran. Jurnal Pendidikan Penabur, No. 4, Th. 4, 2005. Retrieved from http://bpkpenabur.or.id/wpcontent/uploads/2015/10/jurnal-No04-IV-Juli2005.pdf

[5] Hadi W.M, A., Sayhid, A., Yatim, B., Pranowo, B, Ambary, H. M,. Abdullah, I. T,. Madjid, D,. Damami, M, Fathurahman, O,. Putuhena, S,. \& Tjandrasasmita, U. Indonesia dalam Arus Sejarah: Kedatangan dan Peradaban Islam. Jakarta: PT. Ichtiar Baru van Hoeve dan Kemendikbud RI, 2012. 
[6] Martono, N. Metode Penelitian Kualitatif: Analisis Data Sekunder. Jakarta: Rajawali Press. 2011.

[7] SKI Fakultas Adab UIN Yogyakarta. Sejarah Peradaban Islam Indonesia. Yogyakarta: PUSTAKA, 2006.

[8] Sudjana, M dan Ibrahim. Penelitian dan Penilaian. Bandung: Sinar Baru. 2006.

[9] Yatim, B. Sejarah Peradaban Islam. Jakarta: PT. Raja Grafindo Persada, 2008.

[10] Zuchdi, D. Panduan Penelitian Analisis Konten. Yogyakarta: Lembaga Penelitian IKIP Yogyakarta.

[11] Qualitative Analysis Content. https://www.ischool.utexas.edu/ yanz/Content_analysis.p df. Retrivied 10 September 2018
[12] Al-Jawi, M Sidiq. Pendidikan di Indonesia: Masalah dan Solusinya.

http://blog.ub.ac.id/irfan11/files/2013/02/Pendidikan-Di-

Indonesia-oleh-M.-Shiddiq.pdf. Retrivied 30 September 2018

[13] Istiqomah, L. (2016). Dinamika Perubahan Curriculum: Kebijakan Perubahan Curriculum 2013 Paud. Golden Age: Jurnal Ilmiah Tumbuh Kembang Anak Usia Dini, Vol. 1, No. 1. Retrieved from http://ejournal.uinsuka.ac.id/tarbiyah/index.php/goldenage/article/view/124 9

[14] Obaedillah, S. (8 Agustus 2016). Pengadaan Buku K-13 Harus Transparan). Media Indonesia http://mediaIndonesia.com/news/read/60366/pengadaanbuku-k-13-harus-transparan/2016-08-08 